\title{
THE INFLUENCE OF HUMAN RESOURCES ON GRADUATES OF SHARIAH ECONOMICS STUDY PROGRAM OF SUNAN AMPEL STATE ISLAMIC UNIVERSITY OF SURABAYA ON JOB OPPORTUNITIES
}

\author{
Muh. Syaukin Muttaqin \\ STEBI Al-Rosyid Bojonegoro \\ syaukin24@gmail.com
}

\begin{abstract}
This is a field research to highlight the issue of the influence of human resources on graduates of Shariah Economics Study Program of Sunan Ampel State Islamic University of Surabaya on employment opportunities. This issue will be broken down into two fundamental problems, namely; first, is there any influence of human resources on the graduates of Shariah Economics Study Program of Sunan Ampel State Islamic University of Surabaya on employment opportunities? and second, how is the influence of human resources on graduates of Shariah Economics Study Program of Sunan Ampel State Islamic University of Surabaya on employment opportunities? Data is obtained through questionnaire to respondents in the year 2015-2017 with non-probability sampling techniques, namely incidental sampling technique. The results of this study indicate that human resources, economics, and demographics of the graduates of Shariah Economics Study Program of Sunan Ampel State Islamic University of Surabaya have a significant effect on employment opportunities.
\end{abstract}

Keywords: Human resources, economics, demographics, employment opportunities

\begin{abstract}
Abstrak: Ini adalah penelitian lapangan yang membahas tentang pengaruh Sumber Daya Manusia (SDM) lulusan Program Studi Ekonomi Syariah Universitas Islam Negeri Sunan Ampel Surabaya terhadap kesempatan kerja. Tema ini akan diurai melalui dua rumusan masalah, yakni: pertama, apakah ada pengaruh SDM lulusan Program Studi Ekonomi Syariah Universitas Islam Negeri Sunan Ampel Surabaya terhadap kesempatan kerja? dan kedua, bagaimana pengaruh SDM lulusan Program Studi Ekonomi Syariah Universitas Islam Negeri Sunan Ampel Surabaya terhadap kesempatan kerja? Data diperoleh melalui kuesioner kepada responden pada tahun 2015-2017 dengan teknik non probability sampling yaitu teknik incidental sampling. Hasil penelitian ini menunjukkan bahwa sumber daya manusia, ekonomi, dan demografi lulusan Program Studi Ekonomi Syariah Universitas Islam Negeri Sunan Ampel Surabaya berpengaruh signifikan terhadap kesempatan kerja.
\end{abstract}

Kata Kunci: Sumber daya manusia, ekonomi, demografi, kesempatan kerja

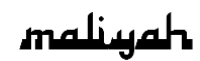

Jurnal Hukum Bisnis Islam

Volume 10, Nomor 02, Desember 2020

p-ISSN: 2088-4869/ e-ISSN: 2597-4351 


\section{Introduction}

Indonesia is one of the countries in the world with the large population, or at least in June 2016 amounting to $257,912,349$ inhabitants. ${ }^{1}$ This large amount is actually the main capital for national development, but on the other hand, this number is precisely a problem that can hamper national development. Therefore, skilled workers will become a major development capital in all fields. ${ }^{2}$ Higher population growth can result in higher labor force growth as well. This means that the more impacts are caused by the higher number of people looking for work. This certainly will cause various problems, one of which is a shortage of jobs that cause unemployment.

Unemployment of the educated workers is one of the macro-economic problems. Some factors that are causing educated workers include, economic crisis, unbalanced employment structure, the need for the number and type of educated workers and the supply of educated workers is not balanced, and the number of labor force is greater than the employment opportunities. ${ }^{3}$ Employment is an indicator of the success of the implementation of education, so the spread of the issue of educated unemployment becomes quite disturbing for educational planning in developing countries in general, especially Indonesia.

Various ways to overcome the problem of unemployment are like demand-side policies, namely by lowering or raising interest rates and increasing government spending followed by a reduction in taxes. ${ }^{4}$ Employment is one of the economic indicators that can be used to measure the

\footnotetext{
${ }^{1}$ Badan Pusat Statistik, "Penduduk Indonesia," within www.bps.go.id.

${ }^{2}$ M.L Jhingan, Ekonomi Pembangunan Dan Perencanaan Terj. D. Guritno (Jakarta: PT. Raja Grafindo Persada, 2003).58

${ }^{3}$ Ibid.59

${ }^{4}$ Sadono Sukirno, Makro Ekonomi, Teori Pengantar (Jakarta: PT. Raja Grafindo Persada, 2004).34
} 
success of regional development. Labor indicators that are often used include the Labor Participation Rate (LPR) and the Open Unemployment Rate (OUR). The higher the Labor Participation Rate (LPR) is the better. It means that the labors' participation will also increase. If the increase in labor is in line with the increase of population's participation, this means an increase in LPR accompanied by a decrease in the participation of the working population. this is a sign that the trigger for the high LPR is the increase in the population looking for work. ${ }^{5}$

The number of unemployed in August 2015 reached 7.6 million people, with the Open Unemployment Rate (OUR) increasing from 5.81 percent in February 2015 to 6.81 percent in August 2015. In August 2015, Open Unemployment Rate (OUR) for vocational high school education occupies the highest position in 12.65 percent, while the lowest Open Unemployment Rate (OUR) was found at the elementary school in 2.74 percent. The number of labor in East Java in 2016 was 19.95 million people, a decrease of 320 thousand compared to 2015. The number of labor in the last 4 years showed a decrease in number. The impact was a decrease in the level of Labor Participation Rate (LPR) in East Java during that time. ${ }^{6}$

The problem of unemployment also occurs in East Java, where the Province of East Java is one of the areas that has a very large population. The economic structure of East Java Province is very specific and has its own characteristics compared to other provinces in Indonesia. In addition, open unemployment in 2015 in East Java was more dominated by urban areas. The flow of urbanization and migration is one of the factors causing the increase in unemployment in urban areas.

An increase in the number of unemployed means that the number of unemployed residents has increased compared

\footnotetext{
${ }^{5}$ Mulyadi S, Ekonomi Sumber Daya Manusia Dalam Perspektif Pembangunan (Jakarta: PT Raja Grafindo Persada, 2003).49

${ }^{6}$ Ibid.
} 
to the previous year. The highest increase in unemployment was found in Kediri with 8.38 percent, and the lowest decrease in unemployment was in Pacitan with 1.12 percent. The next largest increase in unemployment is Sidoarjo, Malang, Pasuruan, and Surabaya. Regencies/cities that have unemployment figures above the provincial average are 17 districts/cities. As many as 5 regencies/cities have Labor Participation Rate (LPR) figures and unemployment rates above the provincial average, namely Kediri, Jombang, Magetan, Bangkalan and Mojokerto. ${ }^{7}$

Getting a decent job is certainly expected by everyone. One effort to get that opportunity is by completing higher education. With the increasing level of competition in the business field and the limited availability of business fields, some people try to improve the quality of their skills. But along with these conditions, the problem arises that many tertiary education graduates are still not absorbed in the business field. One of which is because most college graduates tend not to accept jobs that are not in accordance with the type of expertise and level of education, so that, some of them who did not get work became unemployed. ${ }^{8}$

There are many factors that influence the high level of unemployment, especially for college graduates. In addition to inequality in labor demand and supply, labor issues also involve inequality between the structure of the labor, the structure of employment opportunities, and inequality in the structure of the labor market. Inequality in the structure of the labor and employment opportunities can be seen from the ability of the labor market to absorb at a higher level of education is more limited.

Once over the time, Sunan Ampel State Islamic University, formerly known as Sunan Ampel State Islamic Institute, has nine faculties that have been adapted to the

${ }^{7}$ Ibid.
${ }^{8}$ Ibid. 
development of regional and national development needs, namely Shariah Faculty (Islamic Law), Adab and Humanities Faculty (Humaniora), Social and Political Sciences Faculty, Islamic Economics and Business Faculty, Usuludin Faculty (Islamic Studies), Science and Technology Faculty, Tarbiyah and Teaching Faculty (Education), Da'wah Faculty, and Health and Psychology Faculty. Economics and Islamic Business Faculty has five Study Programs namely Shariah Economics, Economics, Accounting, Management, and Management of Zakat and Waqf. The Shariah Economics Study Program existed firstly in 2009 where it was still Sunan Ampel State Islamic Institute.

In 2014, Sharia Economics left Shariah Faculty and entered Islamic Economics and Business Faculty of Sunan Ampel State Islamic University. Shariah Economics Study Program so far has produced hundreds of graduates who complete education each year. The following is data on the number of graduates of Shariah Economics who completed their education from 2015-2017.

Table 1

Number of Graduates of Shariah Economics Study Program,

Economics and Islamic Business Faculty of Sunan Ampel State Islamic University who completed their education in 2015-20179

\begin{tabular}{|l|l|l|l|}
\hline No. & Periode & \multicolumn{1}{|c|}{ Month } & \multicolumn{2}{c|}{$\begin{array}{c}\text { Bachelor Degree / } \\
\text { Persons }\end{array}$} \\
\hline 1. & 2015 & $\begin{array}{l}\text { March } \\
\text { October }\end{array}$ & $\begin{array}{l}103 \\
73\end{array}$ \\
\hline 2. & 2016 & $\begin{array}{l}\text { March } \\
\text { September }\end{array}$ & 46 \\
& & $\begin{array}{l}\text { January } \\
\text { March }\end{array}$ & 4 \\
\hline 3. & 2017 & & 325 \\
\hline
\end{tabular}

Economics and Islamic Business Faculty of Sunan Ampel State Islamic University of Surabaya, which is one of the

9, 2015-2017 
educational service industries in Surabaya, urgently needs to make continuous improvements in terms of organizing the quality of education so as to produce quality graduates. The study program owned by Economics and Islamic Business Faculty of Sunan Ampel State Islamic University of Surabaya is Shariah Economics Study Program that has B accreditation with No. BAN-PT Accreditation Decree No.028/BAN.PT/Ak.XV/SI/X/2012.

The data above can be assumed that the graduates produced are classified as good or very good. By obtaining accreditation B, the graduates who come from Shariah Economics Study Program should easily adapt and be accepted in the world of work, but only 102 people can be absorbed by employment. Supposedly, the better the accreditation and quality of education, the easier the graduates produced will get a job. There are, however, still many who have not been absorbed as labor in Indonesia.

From the description above the researcher assume that the higher level of education is found, the higher unemployment rate will be. The writer wants to raise the issue of alumni of Shariah Economics Study Program who are not yet absorbed by the workforce in Indonesia. There are some factors that make alumni not absorbed by employment. Therefore, the writer is interested in raising the title about the influence of human resources on graduates of the Economics and Islamic Business Faculty of Sunan Ampel State Islamic University of Surabaya on employment opportunities".

\section{The Concept of Labor in the Vortex of the Labor Market}

The term of employment in English is derived from the word employ, which means an effort to provide work or a source of livelihood. The word employment means the state of people who are currently employed. The use of the term is ordinary expressed for the number of people who are in work 
or have jobs. This understanding has two elements, namely the field opportunities and the people who are employed. ${ }^{10}$

Human resources contain two meanings. First, human resources imply a work effort that can be provided in the production process. Second, human resources related to humans who are able to work to provide services or work effort. Being able to work means being able to carry out activities that have economic value, namely these activities produce goods or services to meet the needs of the community. In other words, people of working age are considered capable of working. The population group in the working age is labor or man power. In short, labor is defined as a population of working age. ${ }^{11}$

In Indonesia, the notion of labor began to be used frequently. Labor includes the labor and the non-labor. The division of labor consists of unemployed and employed, while non-labor includes residents who go to school, take care of the household and receive income. Three groups in the non-labor are such as attending school, receiving income and taking care of the household, even though not working, they are considered physically able to work and at any time can come to work.

Workers are also divided into two groups, namely labor force and not labor force. The labor force are workers or residents of working age who are working or having jobs but are temporarily not working and who are looking for work. While those who are not workers are the workers or residents of working age who are not working, do not have work and are not looking for work, i.e. people whose activities are going to school (students), taking care of the household (housewives),

\footnotetext{
${ }^{10}$ Soeroto, Strategi Pembangunan Dan Perencanaan Tenaga Kerja (Yogyakarta: Gajah Mada University Press, 1983).143

${ }^{11}$ Simanjuntak, Pengantar Ekonomi Sumber Daya Manusia (Jakarta: Fakultas Ekonomi Universitas Indonesia, 2001). 165
} 
as well as recipients of income but are not a direct reward for work service. ${ }^{12}$

The labor force is a population aged 15 years old and who are able to be involved in the production process. Classified as working are those who have been active in activities that produce goods or services or those who during the week before enumeration did work or worked with the intention of earning income for at least 1 hour in the past week. They should not be interrupted. Whereas job seekers (unemployed) are part of the labor force who are currently unemployed and are actively looking for work. ${ }^{13}$

While, the labor market is the overall activity of the actors who bring together between job seekers and job vacancies. These actors consist of employers, job seekers, as well as intermediaries or third parties who make it easy for employers and job seekers to interact. According to Payaman J. Simanjuntak, the process of bringing together between job seekers and job vacancies turned out to take a long time. In this process, both job seekers and employers are exposed to the following facts: ${ }^{14}$

Job seekers have different levels of education, skills, abilities and personal attitudes. On the other hands, each available vacancy has different occupational characteristics. Employers need jobs with education, skills, abilities, even with different personal attitudes. Not all applicants will be suitable for one particular vacancy, thus not all applicants are capable and can be accepted for one particular vacancy.

Every entrepreneur unit faces different environments such as output, input, management, technology, location, market. So, they have different abilities in providing wages,

\footnotetext{
${ }^{12}$ Dumairy, Perekonomian Indonesia (Jakarta: Erlangga, 1996).188

${ }^{13}$ Mulyadi Subri, Ekonomi Sumber Daya Manusia (Jakarta: Raja Grafindo Persada, 2003).241

${ }^{14}$ Payaman J Simanjuntak, Pengantar Ekonomi Sumber Daya Manusia (Jakarta: FE-UI, 1985).145
} 
social security, and work environment. On the other hand, job seekers have different productivity and expectations regarding wage levels and the work environment. Therefore, not all job seekers are willing to accept jobs with the prevailing wage level in a company. On the contrary, not all employers are able and willing to employ an applicant with the level of wages and expectations expressed by the applicant. Both employers and job seekers have limited information about the matters stated in points (1) and (2). Of the many applicants, employers usually use a considerable amount of time to make a selection to find the most appropriate candidate to fill the existing vacancies.

\section{Unemployment and its Impact in the World of Work}

In general, the criteria used to compare economic performance in a certain country under general conditions in the labor market are a high level of unemployment. In general, unemployment is defined as a condition where someone who is in the labor force category does not have a job and is actively looking for work. Someone who does not work, but is actively looking for work cannot be classified as unemployed. To measure unemployment in a country it is usually used what is called the unemployment rate, i.e. the number of unemployed workers is expressed as a percentage of the total labor force. ${ }^{15}$

According to Edy Priyono, unemployed can only be done by the people who have savings or transfers from other people to defend their lives. While, Bellante and Jackson viewed from the causes of their emergence that unemployment can be divided into several types as follows: ${ }^{16}$ First, frictional unemployment, it is unemployment that occurs due to temporary difficulties in bringing together between job seekers and existing job openings. These temporary difficulties can take

\footnotetext{
${ }^{15}$ Alenka Kavle, "Cox Regression Models for Unemployment Duration in Romania, Austria, Slovenia, Croatia Dan Macedonia,"” Romania Journal of Economic Forecasting (2009): 81-104.

${ }^{16}$ Bellante Don, Jackson, and Mark, Ekonomi Ketenagakerjaan (Jakarta: Fakultas Ekonomi Universitas Indonesia, 1990).127
} 
the form of just the time required during the application and selection procedures. Frictional unemployment can also occur due to lack of mobility of job seekers where job vacancies actually exist not in the vicinity of the job seeker's residence.

Second, structural unemployment can occur because of changes in the structure and composition of the economy. Changes in the skills of the workforce are needed while the job seekers are not able to adjust themselves to the new skills. Another form of structural unemployment is the reduction of workers due to the use of tools and advanced technology. Unemployment as a result of changes in the structure of the economy basically requires additional training to acquire new skills that are in line with demand and new technology.

Third, unemployment of educated workers, namely unemployment that often occurs in developing countries where most are workers who have just completed their education and are waiting to get jobs that are in line with their graduation. While waiting for the desired job, their costs are borne by relatively well-off families. This suggests that the problem of unemployment in developing countries is less related to poverty. ${ }^{17}$

Unemployment of educated workers will be more visible especially from the young age group who have just graduated from their education level and are looking for work for the first time. According to Sheenan, in Sutomo's work, it is said that the unemployment rate of young groups is relatively high compared to the unemployment rate of the population. It is caused by several factors, namely structural factors, the low skills of young groups, geographical inequality, age when leaving school, non-structural factors, rising labor rates, increasing women's participation, youth perceptions of

\footnotetext{
17 Tadjuddin Noer Effendi, Sumber Daya Manusia, Peluang Kerja, Dan
} Kemiskinan (Jakarta: Tiara Wacana, 1995).93 
available jobs include low wage rates, career perceptions and work environment. ${ }^{18}$

The impact of unemployment on the economy is that the unemployment can cause people not to be able to maximize the level of welfare they might achieve. Unemployment causes actual output to be lower or under potential output. This situation means that the level of prosperity achieved is lower than the level that might be achieved. In addition, unemployment causes government tax revenue to decrease. Unemployment caused by low levels of economic activity, in turn, will cause tax revenues. High unemployment will inhibit the economic growth. Unemployment also has negative effects on private sector activity.

\section{Human Resources and Job Opportunity Problems}

Human resources have a very significant relationship to a person's chance to get decent work in accordance with their dreams. However, not all human resources are able to be a determinant of the worth and absence of an employment opportunity. This is because human resources have several limitations such as:

First, skill. According to Dunnette, skill is the capacity needed to carry out a number of jobs that are the development of the results of training and experience gained. ${ }^{19}$ Additional skill is usually very helpful for someone in getting a job. The existence of the skills possessed makes a job seeker has added value in the world of work. There are additional skills possessed by job seekers obtained from attending certain courses in accordance with the occupied field. The more skills a person possess, the easier it is for someone to enter the workforce. Conversely, the less someone has additional abilities, the more difficult a person can be accepted into the world of work. It is estimated that with the more skills

\footnotetext{
${ }^{18}$ Sutomo, Perkembangan Pemikiran Ekonomi (Jakarta: LP3ES, 1999).136

${ }^{19}$ Dunnette, Keterampilan Mengaktifkan Siswa (Jakarta: Kencana Prenada Media, 1976). 138
} 
possessed, job seekers are more able to get suitable jobs, in addition to the skills possessed describe the knowledge about labor market.

Second, the waiting period is assumed that the skills possessed will help to get jobs in accordance with their will. In addition, the skills possessed describe the knowledge of workers toward the targeted labor market. By having skills that are supported by higher education, the workforce will have more opportunities to get a job. So that, there is a negative influence between the skills possessed with the length of unemployment or waiting time.

Third, the number of family dependents. According to Vivi Silvia, the size of the workforce can be influenced by the demographic composition of the population and high Labor Force Participation Rate with a large number of working ages will result in a high labor force. From the composition of the population, those included in the number of household dependents are residents who are not included in the workforce, because in general, these residents have not been able to meet their own needs, so they need other people's dependents. ${ }^{20}$

Fourth, geographical factor. Population migration is considered a natural process that will channel surplus labor in remote areas with access to information about job vacancies to areas that have good access to information. According to Mulyadi, the existence of this process led to the rise of population mobility based on the type of work and choosing public areas that are able to provide enough employment even though job seekers have to travel even a long distance from their place of residence to get the desired job. ${ }^{21}$

\footnotetext{
${ }^{20}$ Vivi Silvia, “"Beberapa Faktor Yang Mempengaruhi Tingkat Partisipasi Angkatan Kerja Wanita Di Provinsi Aceh,"” Jurnal Ekonomi dan Bisnis (2009): 91.

${ }^{21}$ Mulyadi, Ekonomi Sumber Daya Manusia Dalam Perspektif Pembangunan.76
} 
The Influence Of Human Resources On Graduates Of Shariah Economics Study Program ...

\section{Determinants of Job Opportunities for Graduates of Shariah Economics Study Program of Sunan Ampel State Islamic University of Surabaya}

The population in this study are all college graduates in Shariah Economics Study Program of Economics and Islamic Business Faculty of Sunan Ampel State Islamic University who graduated in 2015-2017 as many as 325 and who entered the job market both old job seekers and new job seekers, which will then be taken several respondents. The numbers of respondents in this study are 179 people, including graduates from the Sharia Economic Study Program of Economics and Islamic Business Faculty of Sunan Ampel State Islamic University in 2015-2017. Based on the data and information that have been collected, an assessment of the characteristics of respondents will be conducted.

First is respondent's education. One of the determining factors in improving the welfare of the population is education. Education achieved by someone will determine how someone gets a job with high reward. The high level of education achieved by a person is usually related to the desired job and ultimately affects the length of a person's unemployment. One indicator to measure the educational progress of respondents is through the length of study. The following is the amount of time spent completing education from the Shariah Economics Study Program at of Sunan Ampel State Islamic University in 2015-2017 as shown in table 2 below:

Table 2

Number of graduates who finished their study

\begin{tabular}{|l|l|l|l|}
\hline \multirow{4}{*}{ Study Program } & \multicolumn{3}{|c|}{$\begin{array}{c}\text { Graduation of Islamic Economics and } \\
\text { Business Faculty }\end{array}$} \\
\cline { 2 - 4 } & \multicolumn{1}{|c|}{$\begin{array}{c}\text { Length of } \\
\text { Study }\end{array}$} & $\begin{array}{c}\text { Number of } \\
\text { Respondent }\end{array}$ & Percentage \\
\hline \multirow{3}{*}{$\begin{array}{l}\text { Shariah } \\
\text { Economics }\end{array}$} & $>6$ & 2 & 1,1 \\
\cline { 2 - 4 } & $4,5-6$ & 43 & 24 \\
\cline { 2 - 4 } & $4-4,5$ & 78 & 43,6 \\
\cline { 2 - 4 } & $3,5-4$ & 56 & 31,3 \\
\cline { 2 - 4 } & $<3,5$ & & \\
\hline
\end{tabular}


From table 2, it can be seen that graduates who completed their education in the period of 4,5-6 years are 2 respondents with a percentage of $1.1 \%$, in the period of $4-4,5$ years are 43 respondents with a percentage of $24 \%$, in the period of 3,5-4 years are 78 respondents with a percentage of $43.6 \%$, within a period of 3,5 years are 56 respondents with a percentage of $31.3 \%$. Graduates spend an average of 3,5-4 years to complete their education, which is 78 respondents with a percentage of $43.6 \%$.

Second, respondents' skills. The skill of person will determine whether or not someone is quickly accepted into the job market. A worker who has a high level of education may not be accepted directly in a job. Some job vacancies usually list their skills as one of the prerequisites that job seekers must have. The following are the results of research on the length of time to attend the training/skills of respondents obtained before working graduates of the Sharia Economics Study Program of Sunan Ampel State Islamic University in 2015-2017 in Table 3 below:

Table 3

Number of Graduates Attending Training

\begin{tabular}{|c|l|l|l|}
\hline \multirow{3}{*}{$\begin{array}{c}\text { Study } \\
\text { Program }\end{array}$} & \multicolumn{3}{|c|}{$\begin{array}{c}\text { Graduation of Islamic Economics and } \\
\text { Business Faculty }\end{array}$} \\
\cline { 2 - 4 } & $\begin{array}{c}\text { Attending } \\
\text { Trainning }\end{array}$ & $\begin{array}{c}\text { Number of } \\
\text { Respondent }\end{array}$ & Percentage \\
\hline \multirow{3}{*}{$\begin{array}{c}\text { Shariah } \\
\text { Economics }\end{array}$} & $\begin{array}{l}\text { R week } \\
\text { 1 - 2 week }\end{array}$ & 4 & 2,2 \\
\cline { 2 - 4 } & $2-3$ week & 70 & 39,1 \\
\cline { 2 - 4 } & $3-4$ week & 73 & 40,8 \\
\cline { 2 - 4 } & $>1$ month & 32 & 17,9 \\
\hline Total & 179 & 100 \\
\hline
\end{tabular}

Based on table 3, it can be seen that the time needed to conduct training is a maximum of 1 month with 32 respondents with a percentage of $17.9 \%$. The types of skills or courses or non-formal education that they have taken outside of lecture 
hours while taking or after graduating from formal education in college are language courses such as English and Arabic, cooking training at DINKOM, audit training, stock training, accounting system training, basic training in Islamic banking at the Birul Tazkiyah foundation. ${ }^{22}$

Third, respondents' household income. Household income is the income received by all family members used to meet the living needs of all family members for a month. Household income of each graduate is different. This happens because of differences in economic conditions of each household. Someone who has adequate economic conditions can find work longer. While graduates who have weak economic conditions will try to get a job and this will affect the length of a person's unemployed graduate. The following is the number and the average household income of graduates of the Shariah Economics Study Program of Sunan Ampel State Islamic University in 2015-2017 as shown in table 4 below:

Table 4

Average Household Income

\begin{tabular}{|c|l|l|l|}
\hline \multirow{3}{*}{$\begin{array}{c}\text { Study } \\
\text { Program }\end{array}$} & \multicolumn{3}{|c|}{$\begin{array}{c}\text { Graduation of Islamic Economics and } \\
\text { Business Faculty }\end{array}$} \\
\cline { 2 - 4 } & \multicolumn{1}{|c|}{ Income } & $\begin{array}{c}\text { Number of } \\
\text { Respondent }\end{array}$ & Percentage \\
\hline \multirow{3}{*}{$\begin{array}{c}\text { Shariah } \\
\text { Economics }\end{array}$} & $>$ Rp. 10.000 .000 & & \\
\cline { 2 - 4 } & $\begin{array}{l}5.000 .000- \\
10.000 .000\end{array}$ & 3 & 1,7 \\
\cline { 2 - 4 } & $\begin{array}{l}3.400 .000- \\
5.000 .000\end{array}$ & 44 & 24,6 \\
\cline { 2 - 5 } & $\begin{array}{l}1.400 .000- \\
3.400 .000\end{array}$ & 70 & 39,1 \\
\cline { 2 - 5 } & $<$ Rp. 1.400 .000 & 62 & 34,6 \\
\hline Total & & 179 & 100 \\
\hline
\end{tabular}

22 The reason they participated in the training was because of the willingness and ability of their families to pay for attending non-formal education. The perceived non-formal skills they have will add skills and knowledge in addition to the academic education they have so that it will be easier to find job. 
Household income will affect the length of time of a graduate is unemployed. Graduates who have high household incomes when looking for a previous job will be more willing to be unemployed due to the high level of dependency of workers on families so reluctant to look for work. And the increasing desire to work in accordance with the aspirations that families who have high income levels are still willing to bear their children to get work in accordance with their wishes. Whereas families who have low income levels are unable to bear their children to get jobs that they want, so families that are classified as poor are willing to take any jobs to supply their household income.

Fourth, number of respondents' dependents. The number of dependents is one of the reasons for the respondent graduates to immediately work or stay at home while waiting for job vacancies that they wish. The number of dependents of a child/family affects the volume of family needs that must be met. The greater the number of children, the greater the cost of living that must be incurred. The following is the number and percentage of dependents of graduates of the Shariah Economics Study Program of Sunan Ampel State Islamic University in 2015-2017 as shown in table 5 below:

Table 5

Number of Household Dependents

\begin{tabular}{|c|l|l|l|}
\hline \multirow{4}{*}{$\begin{array}{c}\text { Study } \\
\text { Program }\end{array}$} & \multicolumn{3}{|c|}{$\begin{array}{c}\text { Graduation of Islamic Economics and } \\
\text { Business Faculty }\end{array}$} \\
\cline { 2 - 4 } & $\begin{array}{c}\text { Number of } \\
\text { Dependent }\end{array}$ & $\begin{array}{c}\text { Number of } \\
\text { Respondent }\end{array}$ & Percentage \\
\hline \multirow{4}{*}{$\begin{array}{c}\text { Shariah } \\
\text { Economics }\end{array}$} & $1-2$ & & \\
\cline { 2 - 4 } & $2-3$ & 8 & 6,3 \\
\cline { 2 - 4 } & $3-4$ & 68 & 36,1 \\
\cline { 2 - 4 } & $4-5$ & 59 & 33,0 \\
\cline { 2 - 4 } & $>5$ & 44 & 24,6 \\
\hline Total & 179 & 100 \\
\hline
\end{tabular}

Based on table 5, it can be seen the number of dependents of the respondent graduates where the highest number of dependents is 4-5 people and there are 59 
respondents with a percentage of $33.0 \%$. A total of 7 respondents are married and 2 respondents who have a child, while 5 respondents have 2 children. The increasing number of dependents borne in one respondent's family will certainly affect the desire of someone in looking for a job and long unemployed. The more the number of dependents, the more living costs must be incurred and the higher the probability of someone to work. Conversely the less the number of dependents, the less cost of living must be incurred.

Fifth, respondents' distance. Distance is an indicator of demographic variables. Distance is the time taken by alumni from home to work. Job seekers assume employment is more available in areas with good economic mobility, so they look for work near access to information, transportation, and health. The following is the distance between the places of work of respondents of the Shariah Economics Study Program of Sunan Ampel State Islamic University in 2015-2017 as shown in table 6 below:

Table 6

Distance to Work Location

\begin{tabular}{|c|l|l|l|}
\hline \multirow{4}{*}{$\begin{array}{c}\text { Study } \\
\text { Program }\end{array}$} & \multicolumn{3}{|c|}{$\begin{array}{c}\text { Graduation of Islamic Economics and } \\
\text { Business Faculty }\end{array}$} \\
\cline { 2 - 4 } & $\begin{array}{c}\text { Distance to } \\
\text { Work } \\
\text { Location }\end{array}$ & $\begin{array}{c}\text { Number of } \\
\text { Respondent }\end{array}$ & Percentage \\
\hline $\begin{array}{c}\text { Shariah } \\
\text { Economics }\end{array}$ & $>40 \mathrm{~km}$ & & \\
\cline { 2 - 4 } & $40-30 \mathrm{~km}$ & 4 & 2,2 \\
\cline { 2 - 4 } & $30-20 \mathrm{~km}$ & 43 & 24,0 \\
\cline { 2 - 4 } & $20-10 \mathrm{~km}$ & 92 & 51,4 \\
\cline { 2 - 4 } & $<10 \mathrm{~km}$ & 40 & 22,3 \\
\hline Total & & 179 & 100 \\
\hline
\end{tabular}

Based on table 6 shows that the distance of alumni to work is 40-30 kilo meters with 4 respondents with a percentage of $2.2 \%$. At a distance of 30-20 kilo meters with 43 respondents have a percentage of $24.0 \%$. At a distance of $20-10$ kilo meters with 92 respondents have a percentage of 51.4. At 
distances less than 10 kilo meters with 40 respondents have a percentage of $22.3 \%$.

Sixth, waiting time for respondents. Long unemployment means waiting time for a workforce to get a job. This research uses open unemployment, which is time for waiting for an unemployed person to get a job. The following is the number of unemployed respondents who graduated from the Shariah Economics Study Program of Sunan Ampel State Islamic University in 2015-2017 as shown in table 7 below:

Table 7

Waiting Time to Get a Job

\begin{tabular}{|c|l|l|l|}
\hline \multirow{3}{*}{$\begin{array}{c}\text { Study } \\
\text { Program }\end{array}$} & \multicolumn{3}{|c|}{$\begin{array}{c}\text { Graduation of Islamic Economics and } \\
\text { Business Faculty }\end{array}$} \\
\cline { 2 - 4 } & \multicolumn{1}{|c|}{ Jobless } & \multicolumn{1}{|c|}{$\begin{array}{c}\text { Number of } \\
\text { Respondent }\end{array}$} & Percentage \\
\hline \multirow{3}{*}{$\begin{array}{c}\text { Shariah } \\
\text { Economics }\end{array}$} & $<1$ month & & \\
\cline { 2 - 4 } & $1-3$ month & 3 & 1,7 \\
\cline { 2 - 4 } & $3-6$ month & 48 & 26,8 \\
\cline { 2 - 4 } & $6-9$ month & 89 & 49,7 \\
\cline { 2 - 4 } & $>12$ month & 39 & 21,8 \\
\hline Total & 179 & 100 \\
\hline
\end{tabular}

Based on table 7 above, it can be explained that the respondents' unemployment time for 1-3 months is 3 respondents have a percentage of $1.7 \%$. 3-6 months with 48 respondents have a percentage of $26.8 \%$. 6-9 months with 89 respondents have a percentage of $49.7 \%$. Over 12 months with 39 respondents haveh a percentage of $21.8 \%$. Long time unemployed with a relatively longer time is more than 12 months with 39 respondents.

\section{Simultaneous Effect of Human Resources, Economics and Demographics on Waiting Time for Alumni of Shariah Economics Study Programs}

Based on the data above, human resources, economics and demographics have a very simultaneous effect on waiting time for alumni of Shariah Economics Study Program. It shows $\mathrm{F}$ test that has been carried out that the $\mathrm{F}$ count shows a value 
of 19,620 with a significant result of 0,000 , set the degree of freedom 2 (n-k-1, 179-3-1 = 175) on the number 175 and in the F table obtained at 2.66 , so calculated $F$ value of 19,620 is greater than the value of $\mathrm{F}$ table $=2.66$. From the results of the F statistical tests that have been carried out, it is evident that human resources, economics, and demographics simultaneously have a significant influence on the waiting time for the Alumni of Shariah Economics Study Program.

Waiting time is identical to the duration of unemployment which the average length of time a graduate remains unemployed. The period of waiting to get a job for someone can be used as a rough indicator of the level of labor shortages in a particular field. So a person graduates a stage in finding a job is the main and most important thing. It is because when graduates find work it will emerge the intention and willingness of graduates to get the desired job.

In general, waiting time or unemployment is defined as a condition where someone who is in the labor force category does not have a job and is actively looking for work. Waiting time also means waiting for someone in the workforce to get a job. Understand how the human recourses, economic and demographic resources factors are able to influence graduates in deciding to find a decent job and in accordance with the level they have taken.

\section{The Effect of Human Resources, Economics, and Demographics Partially on Waiting Time for Alumni of Islamic Economics Study Programs}

The Influence of human resources partially on the waiting time for alumni of Shariah Economics Study Program is in the skill indicators. The skills possessed by a job seeker will be more able to get suitable jobs, besides the skills possessed by someone can describe the knowledge of the job market. By having skill supported with high education, the workforce will have more opportunities to get a job. 
Based on the results of the T test, the human resources variable (X1) shows the calculated $t$ value is 2.790 and the $t$ table value is 1.973. Because the significance value is less than 0.006 from 0.05 , so $\mathrm{H} 0$ is rejected and $\mathrm{H} 1$ is accepted. There is a significant positive effect partially from the human resources variable (X1) on the waiting time of alumni in getting a job. Human resources partially influence the waiting time for the alumni of the Shariah Economics Study Program. In theory, individuals who have skill will get job faster than people who lack skill. This is because the higher the skill they have, the smaller the job they choose.

This research is relevant to the existing research, such as Ni Kadek Meindrayani's research. The result of this study indicate that there is a positive influence of skill on alumni's waiting time to get a job. This research also supports previous research conducted by Ratih Pertiwi. The result of the study that undergraduate education variables have a positive effect on waiting time for alumni to get a job. According to Sutomo in Setiawan, by having skill supported with high education, the workforce will have more opportunities to get a job. This generally provides an understanding that the more skills graduates possess will have a positive effect on waiting time to get a job.

Partial economic influences on the waiting time for the alumni of the Shariah Economics Study Program. The economic factor, with the indicator of household income owned by one family, is very influential and determines a person's desire to be willing to work in the labor market or not. People whose economies are still relatively low are generally unable to continue their education and are forced to look for work to meet their daily needs, so that the length of time to look for work is longer. This is because job seekers who have rich family are willing to wait longer in the hope of getting a better wage, social security, and work environment.

According to Simanjuntak, if a family has a good household income, the family is able to pay their unemployed 
children for another one to two years in the process of finding a better job. However, in contrast, educated job seekers who usually come from poor families are unable to remain unemployed longer and are forced to accept whatever work is available. Another factor that has a significant effect is the number of dependents on the family. The number of dependents family can be a reason for a job seeker to immediately find work. The decision is a step to overcome the powerlessness in meeting the needs of life.

This research is relevant to the existing research, such as Ni Kadek Meindrayani's research that household income and household dependents have a positive and significant influence on the duration of unemployment of graduates. This research is also in accordance with research conducted by A. Ihsan Triputrajaya. The result of the study shows that household income has a positive effect on waiting time for alumni to get work.

Partial demographic influences on the Alumni's waiting time of the Shariah Economics Study Program. There are always a number of obstacles faced by job seekers in getting their jobs. One obstacle faced is the distance between the source of work information and the distance of the residence of the job seeker. The longer the distance traveled to get information related to the job to be sought, the longer the desire for someone to get a job. Conversely, if the distance between the residence and the city is near, it will be easy to get a job.

This is consistent with the theory which states that someone who lives closer to the area of good job vacancies, he will have a lot of access that can shorten the waiting time for work. Greater job opportunities and more complete facilities and infrastructure make it easier for someone to get a job.

Given the limited scope of information and access both in terms of human and economic resources to get ease in getting a job is one of the reasons of a person's desire to work immediately or not. This study is a little bit different to the

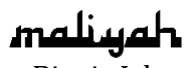


existing research, such as Ratih Pratiwi's research, that distance has a negative effect on respondent's unemployment time. While this research is relevant to the existing research of $\mathrm{Ni}$ Kadek Meindrayani's research that the distance has positive and significant influence on the duration of unemployed graduates in getting a job.

\section{Closing}

Based on the discussion above, it can be concluded that:

First, the results of the $\mathrm{F}$ statistical tests that have been carried out, it is evident that human resources, economics, and demographics simultaneously have a significant influence on the graduates' waiting time of the Shariah Economics Study Program. This is evidenced from the calculated $F$ value of 19,620 which is greater than the $F$ table value of 2.66 with a significance of 0,000 .

Second, the human resource variable (X1) is a t-count value of 2,790 , $t$-table value of 1,973 . Because the significance value is less than 0.006 from 0.05 , so, $\mathrm{H} 0$ is rejected and $\mathrm{H} 1$ is accepted. In this case, there is a significant positive effect partially from the human resources variable (X1) on the waiting time for alumni in getting a job. In the Economy variable (X2), the calculated $t$ value of $2.172 \mathrm{t}$ table value of 1.973. Because the significance value is less than 0.031 from 0.05 , so, $\mathrm{H} 0$ is rejected and $\mathrm{H} 1$ is accepted. In this case, there is a significant positive influence partially from economics (X2) on the waiting time for alumni in getting a job. Then in the demographic variable (X3), the $t$-value is 2.761 and $t$ tables is 1,973 . Because the significance value is smaller than 0.006 from $0.05, \mathrm{HO}$ is rejected and $\mathrm{H} 1$ is accepted. In this case, there is a significant positive effect partially from demography (X3) on the waiting time of alumni in getting a job.

\section{Bibliography}

Don, Bellante, Jackson, and Mark. Ekonomi Ketenagakerjaan. Jakarta: Fakultas Ekonomi Universitas Indonesia, 1990. Dumairy. Perekonomian Indonesia. Jakarta: Erlangga, 1996. 
Dunnette. Keterampilan Mengaktifkan Siswa. Jakarta: Kencana Prenada Media, 1976.

Effendi, Tadjuddin Noer. Sumber Daya Manusia, Peluang Kerja, Dan Kemiskinan. Jakarta: Tiara Wacana, 1995.

Jhingan, M.L. Ekonomi Pembangunan Dan Perencanaan Terj. D. Guritno. Jakarta: PT. Raja Grafindo Persada, 2003.

Kavle, Alenka. "'Cox Regression Models for Unemployment

Duration in Romania, Austria, Slovenia, Croatia Dan Macedonia."' Romania Journal of Economic Forecasting (2009):

S, Mulyadi. Ekonomi Sumber Daya Manusia Dalam Perspektif

Pembangunan. Jakarta: PT Raja Grafindo Persada, 2003. Silvia, Vivi. “'Beberapa Faktor Yang Mempengaruhi Tingkat Partisipasi Angkatan Kerja Wanita Di Provinsi Aceh."' Jurnal Ekonomi dan Bisnis (2009):

Simanjuntak. Pengantar Ekonomi Sumber Daya Manusia.

Jakarta: Fakultas Ekonomi Universitas Indonesia, 2001. Simanjuntak, Payaman J. Pengantar Ekonomi Sumber Daya Manusia. Jakarta: FE-UI, 1985.

Soeroto. Strategi Pembangunan Dan Perencanaan Tenaga Kerja. Yogyakarta: Gajah Mada University Press, 1983.

Statistik, Badan Pusat. "Penduduk Indonesia." within www.bps.go.id.

Subri, Mulyadi. Ekonomi Sumber Daya Manusia. Jakarta: Raja Grafindo Persada, 2003.

Sukirno, Sadono. Makro Ekonomi, Teori Pengantar. Jakarta: PT. Raja Grafindo Persada, 2004.

Sutomo. Perkembangan Pemikiran Ekonomi. Jakarta: LP3ES, 1999. 